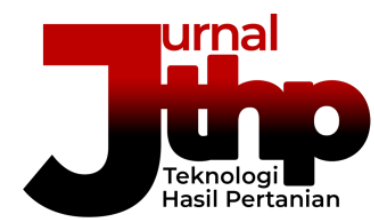

Jurnal Teknologi Hasil Pertanian. 14(2), 117-130

URL: https://jurnal.uns.ac.id/ilmupangan/article/view/54338

DOI: https://doi.org/10.20961/jthp.v14i2.54338

ISSN 1979-0309 (Online) 2614-7920 (Print)

\title{
MODIFIKASI PATI HANJELI (Coix lacryma-jobi L.) BERPORI MELALUI ULTRASONIKASI DAN OZONASI
}

\author{
MODIFICATION OF POROUS ADLAY (Coix lacryma-jobi L.) STARCH BY \\ ULTRASONICATION AND OZONATION
}

\author{
Edy Subroto, Rossi Indiarto, Endah Wulandari, Astri Puji Astari \\ Departemen Teknologi Industri Pangan, Fakultas Teknologi Industri Pertanian, Universitas Padjadjaran. \\ Jl.Raya Bandung-Sumedang Km. 21, Jatinangor, Sumedang 40600, Indonesia. \\ email: edy.subroto@unpad.ac.id
}

Diserahkan [13 Agustus 2021]; Diterima [21 Oktober 2021]; Dipublikasi [13 November 2021]

\begin{abstract}
Adlay (Coix lacryma-jobi L.) is a potential source of starch but has not been utilized optimally. Native adlay starch has several weaknesses such as functional properties of low swelling volume and solubility, prone to retrogradation, and low stability. Physical modification of ultrasonication and chemical modification by oxidation using ozone can be an alternative to improve the functional properties of adlay starch through the formation of porous starch. The aim of this research was to produce porous adlay starch by ultrasonication and ozonation. The study consisted of several different treatments on hanjeli starch (ozonation starch, ultrasonication of 15 minutes, ultrasonication of 30 minutes, combined ultrasonication of 15 minutes and 30 minutes with ozonation). The results showed the appearance of pores on the surface of the granules of modified adlay starch with the best results being modified combination of ultrasonication 30 minutes and ozonation, which resulted in a decrease in swelling volume from $18.13 \pm 3.98 \mathrm{~mL} / \mathrm{g}$ to $15.71 \pm 0.35 \mathrm{~mL} / \mathrm{g}$, an increase in solubility from $6.76 \pm 0.62 \%$ to $9.59 \pm 0.44 \%$, and a decrease in water absorption capacity from $1.25 \pm 0.02 \mathrm{~g} / \mathrm{g}$ to $1.13 \pm 0.02 \mathrm{~g} / \mathrm{g}$. Modification of adlay starch by ultrasonication, ozonation, and their combination effectively produced porous starch granules, but did not cause the formation of new functional groups in starch.
\end{abstract}

Keywords: Adlay; starch modification; ozonation; ultrasonication

\section{ABSTRAK}

Hanjeli (Coix lacryma-jobi L.) adalah salah satu komoditas penghasil pati yang potensial tetapi belum dimanfaarkan secara optimal. Pati hanjeli alami memiliki beberapa kekurangan seperti sifat fungsional swelling volume dan solubility yang rendah, rentan retrogradasi, dan stabilitas yang rendah. Modifikasi fisik ultrasonikasi dan modifikasi kimia dengan oksidasi menggunakan ozon dapat menjadi alternatif untuk memperbaiki sifat fungsional pati hanjeli melalui pembentukan pati berpori. Tujuan dari penelitian ini untuk menghasilkan pati hanjeli berpori melalui modifikasi ultrasonikasi dan ozonasi. Penelitian terdiri dari beberapa perlakuan yang berbeda pada pati hanjeli (pati ozonasi, ultrasonikasi 15 menit, ultrasonikasi 30 menit, kombinasi ultrasonikasi 15 dan 30 menit dengan ozonasi). Hasil penelitian menunjukkan munculnya pori-pori pada permukaan granula pati termodifikasi dengan hasil terbaik yaitu modifikasi kombinasi ulrasonikasi 30 menit dan ozonasi, pengujian dengan FTIR menunjukkan tidak adanya perubahan yang signifikan pada gugus fungsional pati modifikasi, sifat fungsional pati setelah modifikasi kombinasi ultrasonikasi 30 menit dan ozonasi menghasilkan penurunan swelling volume dari $18,13 \pm 3,98 \mathrm{~mL} / \mathrm{g}$ menjadi $15,71 \pm 0,35 \mathrm{~mL} / \mathrm{g}$, peningkatan solubility dari $6,76 \pm 0,62 \%$ menjadi 9,59 $\pm 0,44 \%$, dan penurunan kapasitas penyerapan air dari 1,25 $\pm 0,02 \mathrm{~g} / \mathrm{g}$ menjadi 1,13 $\pm 0,02 \mathrm{~g} / \mathrm{g}$. Modifikasi pati hanjeli dengan ultrasonikasi, ozonasi, dan kombinasi keduanya efektif menghasilkan pori-pori pada permukaan granula pati, tetapi tidak menyebabkan pembentukan gugus fungsional baru pada pati.

Kata Kunci : Hanjeli; modifikasi pati; ozonasi; ultrasonikasi.

Saran sitasi: Subroto, E., Indiarto, R., Wulandari E., \& Astari, A. P. 2021. Modifikasi Pati Hanjeli (Coix lacryma-jobi L.) Berpori Melalui Ultrasonikasi dan Ozonasi. Jurnal Teknologi Hasil Pertanian, 14(2), 117-130. https://doi.org/10.20961/jthp.v14i2.54388 


\section{PENDAHULUAN}

Hanjeli merupakan tanaman serealia yang dikenal sebagai adlay, job's tears, atau chinese pearl barley (Zhu, 2017). Komponen utama hanjeli yaitu pati berkisar $54.26 \%$ $58.15 \%$ dari berat keringnya, namun pati hanjeli belum dimanfaatkan secara optimal (Chaisiricharoenkul et al., 2011; Capule dan Trinidad, 2016). Pati alami memiliki kelemahan seperti rentan terhadap retrogradasi dan sineresis, tidak tahan terhadap perubahan $\mathrm{pH}$, suhu, atau perlakuan mekanis (Przetaczek-Rożnowska et al., 2019).

Beberapa kekurangan pada karakteristik pati hanjeli alami dapat diperbaiki dengan perlakuan modifikasi pati, sehingga sifat fungsionalnya dapat disesuaikan dengan yang diinginkan dan dapat diaplikasikan pada berbagai industri secara tepat (Nanci Castanha et al., 2019). Modifikasi pati menjadi pati berpori telah berkembang pesat untuk memperoleh pati dengan kemampuan penyerapan yang baik. Pati berpori dapat digunakan sebagai adsorben yang baik dan tidak beracun yang kapasitas penyerapannya berasal dari luas permukaan granula pati (Zhang et al., 2012). Pada industri pangan, pati berpori dapat digunakan untuk mengontrol pelepasan warna, rempahrempah, perasa, pemanis, dan juga perlindungan bahan sensitif seperti vitamin (misalnya vitamin $\mathrm{E}$ dan $\mathrm{A}$ ), komponen bioaktif, pigmen makanan (misalnya karoten dan likopen) yang sensitif terhadap cahaya, oksidasi, dan suhu tinggi (Comin et al., 2012; Mi et al., 2012; Wu et al., 2011).

Modifikasi pati berpori dapat dilakukan dengan metode fisik, kimia, enzimatis, atau dengan kombinasinya yang disebut modifikasi ganda (Ashogbon dan Akintayo, 2014; Deka dan Sit, 2016; Halal et al., 2015; Majzoobi et al., 2015). Ultrasonikasi merupakan metode modifikasi fisik pati yang akan menghasilkan pembentukan permukaan granula pati yang berpori (Falsafi et al., 2019). Pengaruh ultrasonikasi pada partikel/granula pati tergantung pada beberapa faktor seperti durasi proses ultrasonikasi, intensitas, frekuensi, suhu, serta jenis dan struktur pati (Zhu, 2015).
Keuntungan dari modifikasi ultrasonikasi pada pati yaitu menghasilkan pati berpori dengan kualitas yang lebih tinggi, mengurangi penggunaan bahan kimia, mengurangi waktu pemrosesan, dan ramah lingkungan (Chemat et al., 2011; Zuo et al., 2009).

Modifikasi fisik ultrasonikasi pada pati dapat dikombinasikan dengan modifikasi secara kimiawi (Hu et al., 2019). Modifikasi secara kimiawi dapat dilakukan dengan metode oksidasi menggunakan oksidator kuat seperti ozon, Ozon merupakan oksidator yang ramah lingkungan karena tidak meninggalkan residu pada produk ataupun lingkungan (Cahyana et al., 2018). Penelitian terkait ozonasi pada pati dilaporkan dapat memperbaiki sifat fungsional pati (Sandhu et al., 2012). Modifikasi ganda pada pati melalui ultrasonikasi dan ozonasi berpotensi dapat memperbaiki sifat fungsional secara signifikan. Namun demikian, informasi terkait modifikasi kombinasi ultrasonikasi dan ozonasi terhadap pati hanjeli masih terbatas. Oleh sebab itu dilakukan modifikasi ultrasonikasi yang dilanjutkan dengan ozonasi untuk memperoleh pati berpori sekaligus memperbaiki sifat fungsional dan sifat amilografi pati hanjeli.

\section{METODE PENELITIAN}

\section{Bahan}

Bahan yang digunakan adalah beras hanjeli varietas mayuen, dari Majalengka, Jawa Barat, serta bahan penunjang antara lain air bersih, akuades, es batu, metalized pouch, larutan $\mathrm{NaOH} 0,3 \%$, oksigen, plastik polypropylene (PP), dan silica gel.

\section{Alat}

Alat-alat yang digunakan dalam pembuatan pati hanjeli modifikasi antara lain ayakan 100 mesh, chamber, grinder, kain saring, oven, ozonizer yang dibuat oleh FTIP-Unpad, dan ultrasonicator. Alat untuk analisis antara lain breaker glass, gelas ukur, neraca analitik, pipet tetes, RVA (Rapid Visco Analyzer), Scanning Electron Microscope (SEM) JEOL JSM6510 LA, tabung sentrifugasi, sentrifuse, termometer, vortex, dan waterbath. 


\section{Tahapan Penelitian}

Penelitian menggunakan Rancangan Acak Kelopok (RAK) dengan percobaan terdiri dari 6 perlakuan. Adapun perlakuan yang dicoba sebagai berikut:

$\mathrm{A}=$ Pati hanjeli alami (kontrol)

$\mathrm{B}=$ Pati hanjeli modifikasi ozonasi flowrate

$2 \mathrm{~L} /$ menit

$\mathrm{C}=$ Pati hanjeli modifikasi ultrasonikasi 15 menit

$\mathrm{D}=$ Pati hanjeli modifikasi ultrasonikasi 30 menit

$\mathrm{E}=$ Pati hanjeli modifikasi ultrasonikasi 15 menit dan ozonasi flowrate $2 \mathrm{~L} /$ menit

$\mathrm{F}=$ Pati hanjeli modifikasi ultrasonikasi 30 menit dan ozonasi flowrate $2 \mathrm{~L} /$ menit Adapaun tahapan penelitian ini terdiri dari:

\section{Ekstraksi Pati Hanjeli}

Ekstraksi pati hanjeli mengacu pada Capule dan Trinidad (2016). Tepung hanjeli direndam 24 jam dalam $\mathrm{NaOH} 0,3 \%$ dengan rasio bahan dengan pelarut 1:3 (b/v), kemudian dilakukan filtrasi (penyaringan) menggunakan kain saring, filtrat yang dihasilkan diendapkan selama 24 jam, sedangkan ampasnya direndam kembali dalam larutan $\mathrm{NaOH} 0,3 \%$ selama 5 menit, pengendapan ampas tersebut dilakukan pengulangan satu kali lagi. Endapan pati yang dihasilkan setelah pengendapan filtrat selama 24 jam kemudian dicuci sebanyak 3 kali menggunakan air bersih, lalu dilakukan pengeringkan pada suhu $50^{\circ} \mathrm{C}$ selama $17 \mathrm{jam}$, pati selanjutnya digiling dan dilakukan pengayakan 100 mesh.

\section{Pati Hanjeli Modifikasi Ultrasonikasi}

Modifikasi ultrasonikasi pati hanjeli mengacu pada Sujka dan Jamroz (2013). Pati hanjeli disuspensikan dengan akuades (30 $\mathrm{b} / \mathrm{v})$, kemudian dilakukan proses ultrasonikasi menggunakan Ultrasound Probe MODEL CL-334 Seri 20130807 pada frekuensi $25 \mathrm{kHz}$, daya 500 Watt, suhu 30$35^{\circ} \mathrm{C}$, selama 15 menit dan 30 menit. Suspensi pati kemudian disentrifugasi pada $3500 \mathrm{rpm}, 30$ menit, lalu hasil endapannya dikeringkan dengan udara panas menggunakan pengering kabinet pada $50^{\circ} \mathrm{C}$ selama 17 jam. Pati selanjutnya dilakukan penggilingan dan dilakukan pengayakan 100 mesh.

\section{Pati Hanjeli Modifikasi Ozonasi}

Modifikasi ozonasi pati hanjeli mengacu pada Sandhu et al. (2012). Pati hanjeli alami dan modifikasi ultrasonikasi sebanyak $100 \mathrm{~g}$ dimasukan ke dalam chamber berukuran 250 $\mathrm{mL}$, kemudian dilakukan proses ozonasi secara batch untuk masing-masing perlakuan sambil dilakukan pengadukan dengan flowrate $2 \mathrm{~L} /$ menit selama 20 menit. Setelah itu, pati hasil proses ozonasi dilakukan pengadukan selama 5 menit.

\section{Granula Pati}

Analisis bentuk dan permukaan granula pati hanjeli dilakukan dengan Scanning Electron Microscope (SEM JEOL-JSM6510, JEOL Ltd.Tokyo Japan). Pati hanjeli diletakkan pada sample holder menggunakan isolasi double-side. Sampel pati hanjeli diberi lapisan emas, kemudian ditempatkan dalam instrument SEM, dan dilakukan pembacaan morfologi granula pati hanjeli pada skala pembesaran 2000 dan 7000 kali.

\section{Gugus Fungsional Pati Dengan Fourier Transform Infrared Spectroscopy (FTIR)}

FTIR (Nicolet iS10 FTIR spectrometer, ThermoFisher Scientific, USA) dikombinasikan dengan attenuated total reactance (ATR) digunakan untuk analisis gugus fungsional pati. Persiapan sampel pati hanjeli (1-2 mg), lalu ditambahkan bubuk $\mathrm{KBr}$ murni $(200 \mathrm{~g})$ dan diaduk hingga homogen. Campuran sampel diletakkan pada cetakan atau tempat sampel kemudian dilakukan penekanan dan dipertahankan beberapa menit. Kemudian, dilakukan pengambilan sampel pada alat spektroskopi inframerah untuk dianalisis.

\section{Sifat Fungsional}

\section{Swelling Volume dan Solubility}

Sampel pati hanjeli 0,35 g dimasukan ke tabung sentrifugasi ukuran $50 \mathrm{~mL}$, dan ditambahkan 12,5 ml akuades, lalu divortex 30 detik. Sampel dilakukan pemanasan pada $80^{\circ} \mathrm{C}, 30$ menit dalam waterbath. Sampel kemudian direndam dalam air dingin $\left( \pm 5^{\circ} \mathrm{C}\right)$ selama 1 menit, kemudian disentifugasi pada 
$3500 \mathrm{rpm}, 30$ menit pada suhu ruang $( \pm$ $25^{\circ} \mathrm{C}$ ) sehingga terjadi pemisahan antara supernatant dan gel. Gel dan supernatan pada tabung sentrifugasi dipisahkan, kemudian supernatan diukur volumenya. Supernatan kemudian dikeringkan pada $110^{\circ} \mathrm{C}$ selama 24 jam, kemudian ditimbang beratnya (Collado dan Corke, 1999).

\section{Kapasitas Penyerapan Air}

Sampel pati hanjeli $1 \mathrm{~g}$ dalam tabung sentrifugasi ukuran $50 \mathrm{~mL}$ ditambah dengan akuades $10 \mathrm{ml}$, kemudian perlakuan vortex 30 detik dan didiamkan 30 menit, lalu dilakukan sentrifugasi pada $3500 \mathrm{rpm}, 30$ menit. Supernatan yang dihasilkan dipisahkan dari endapan, kemudian ditimbang (Beuchat, 1977).

\section{Sifat Amilografi Pati}

Sampel pati hanjeli $\pm 3,5$ g dimasukkan dalam canister alumunium, lalu ditambah akuades sebanyak $\pm 25 \mathrm{ml}$. Canister yang berisi pati hanjeli dan akuades dipasang pada alat Rapid Visco Analyzer (RVA) (RVASM2, Warriewood Australia). Pengujian menggunakan siklus pemanasan dan pendinginan dengan pengandukan konstan pada suhu $50^{\circ} \mathrm{C}$, lalu dilakukan penahanan selama 1 menit pada suhu $50^{\circ} \mathrm{C}$. Pemanasan dilanjutkan hingga mencapai suhu $95^{\circ} \mathrm{C}$ dengan kecepatam $8,4^{\circ} \mathrm{C} /$ menit, lalu dilakukan penahanan pada suhu $95^{\circ} \mathrm{C}$ selama 1,6 menit. Pendinginan sampel dilakukan dengan kecepatan $11,86^{\circ} \mathrm{C} /$ menit hingga mencapai suhu $50^{\circ} \mathrm{C}$ (Subroto et al., 2019).

\section{HASIL DAN PEMBAHASAN}

\section{Permukaan Granula Pati}

Karakteristik granula pati dianalisis menggunakan SEM untuk mengetahui apakah proses modifikasi memiliki pengaruh pada morfologi pati hanjeli. Analisis SEM pati hanjeli ditunjukkan pada Gambar 1. Berdasarkan hasil analisis SEM pati hanjeli alami bentuknya bulat dan tidak beraturan dengan permukaannya yang relatif halus tidak berpori. Hasil serupa dilaporkan oleh Miao et al., (2018) yang menghasilkan granula pati hanjeli yang berbentuk bulat, polygonal, dan tidak beraturan berdasarkan analisis SEM. Pati hanjeli modifikasi ozonasi menunjukkan permukaan granula yang memiliki pori-pori berukuran kecil. Kerusakan granula pati atau terbentuknya pori-pori terjadi pada permukaan granula, dan dengan semakin banyaknya pori-pori maka granula pati diharapkan memiliki kemampuan penyerapan yang tinggi. Hal tersebut disebabkan sebagian besar oksidasi terjadi pada permukaan granula karena aksesibilitasnya yang tinggi (Sumardiono et al., 2021). Hal ini hampir sama dengan hasil yang diperoleh Castanha et al. (2019), yang melaporkan bahwa modifikasi oksidasi dengan ozon menghasilkan granula pati berpori. Pati hanjeli modifikasi ultrasonikasi diduga tidak mengalami perubahan pada bentuk granula pati, yaitu masih berbentuk bulat dan sebagian tidak beraturan, hal ini didukung oleh Amini et al., (2015) dan Sujka dan Jamroz (2013) yang menyatakan bahwa ultrasonikasi tidak berpengaruh secara signifikan terhadap bentuk granula pati. Namun demikian, permukaan granula pati hanjeli dengan ultrasonikasi menjadi tidak rata dan bepori dengan ukuran pori-pori yang cukup besar. Munculnya pori pada granula pati disebabkan karena selama proses ultrasonikasi terjadi runtuhnya gelembung kavitasi yang menghasilkan tekanan tinggi di sekitar granula, sehingga menyebabkan gaya geser yang dapat merusak granula pati (Majzoobi et al., 2015). Adanya pori-pori pada permukaan granula dapat disimpulkan bahwa tempat terjadi pecahnya gelembung kavitasi yaitu di permukaan granula pati (Falsafi et al., 2019).

Gambar 1 menunjukkan bahwa perlakuan ultrasonikasi 30 menit menghasilkan pori yang lebih banyak dibandingkan dengan perlakuan 15 menit, hal ini mencerminkan bahwa semakin lama waktu proses ultrasonikasi pada pati maka menghasilkan permukaan pati berpori yang meningkat (Majzoobi et al., 2015; Zuo et al., 2009). Hasil penelitian ini sejalan dengan hasil temuan $\mathrm{Hu}$ et al., (2015), yang menunjukkan bahwa setelah dilakukan proses ultrasonikasi, struktur granula pati jagung memiliki banyak pori di permukaannya. Pati hanjeli dengan modifikasi kombinasi ultrasonikasi dan ozonasi diduga tidak mengalami perubahan 
pada bentuk granula pati, hal ini didukung oleh penelitian Castanha et al., (2019) yang melaporkan bahwa perlakuan kombinasi ultrasonikasi dan ozonasi tidak menyebabkan perubahan nyata pada bentuknya. Modifikasi ultrasonikasi dan ozonasi pati hanjeli menghasilkan pori-pori yang lebih banyak pada permukaan granulanya, namun tidak signifikan dibandingkan pati ultrasonikasi.

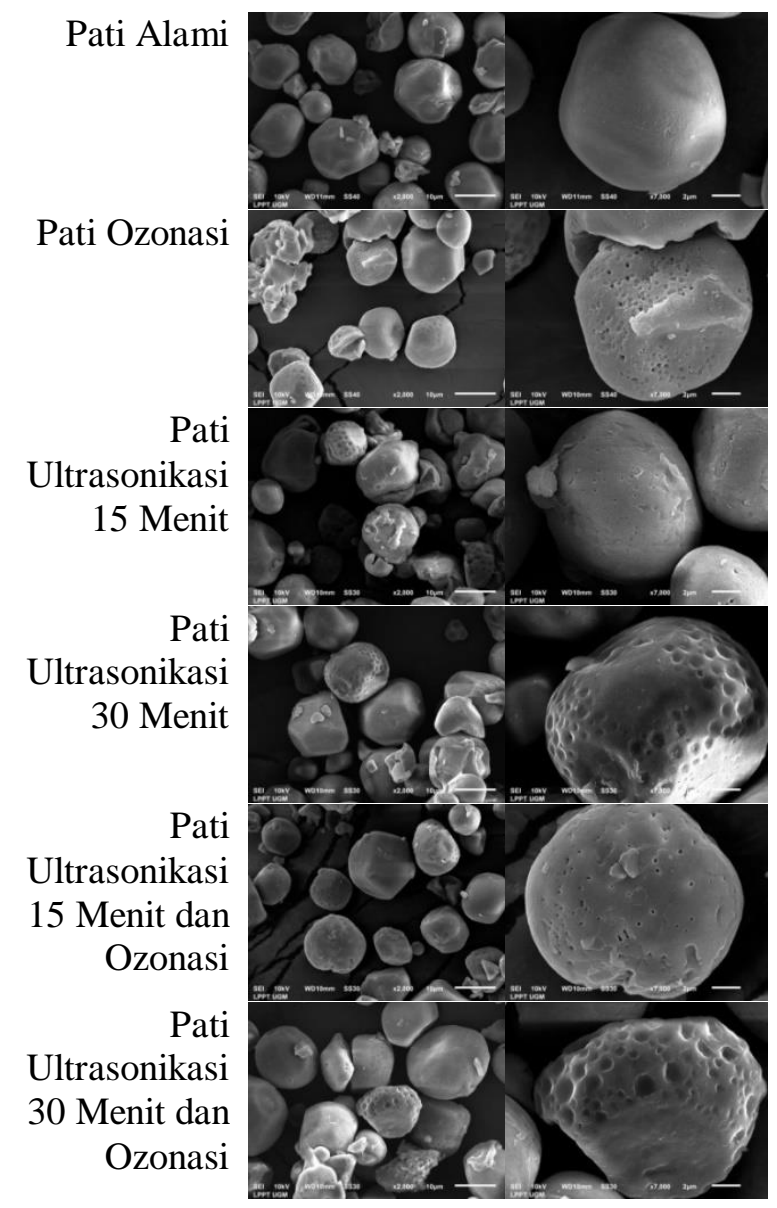

Gambar 1 Morfologi Granula Pati Hanjeli Alami dan Modifikasi menggunakan SEM.

\section{Gugus Fungsional Pati Dengan FTIR (Fourier Tansform Infrared Spectroscopy)}

FTIR digunakan juga untuk mengetahui perubahan struktur kimia molekul pati yang dihasilkan setelah perlakuan modifikasi (Kang et al., 2016). Spektroskopi tersebut akan menunjukkan banyak puncak (peak) sebagai representasi dari kelompok gugus fungsional yang ada dalam sampel. Analisis spektrum FTIR pati hanjeli alami, ozonasi, serta kombinasi ultrasonikasi dan ozonasi disajikan pada Gambar 2. Semua sampel pati termodifikasi tidak terdapat perubahan yang signifikan. Hal ini menandakan bahwa modifikasi pati dengan ozonasi serta kombinasi ultrasonikasi dan ozonasi tidak menyebabkan hilangnya ataupun munculnya gugus fungsional baru pada pati, sehingga gugus fungsi pati berpori hasil modifikasi hampir sama dengan pati hanjeli alami.

Sprektum FTIR pati menunjukkan puncak pada bilangan gelombang 3397-3398 $\mathrm{cm}^{-}$, puncak ini menunjukkan adanya gugus O-H. Puncak selanjutnya tidak ada perubahan bilangan gelombang pada sampel modifikasi yaitu $2929 \mathrm{~cm}^{-}$, puncak ini menunjukkan adanya gugus $\mathrm{C}-\mathrm{H}$. Puncak selanjutnya dengan bilangan gelombang pada sampel modifikasi yaitu $1640 \mathrm{~cm}^{-}$, puncak ini menunjukkan adanya gugus $\mathrm{C}=\mathrm{C}$. Puncak dengan bilangan gelombang 1079-1080 cm puncak ini menunjukkan adanya gugus $\mathrm{C}-\mathrm{O}$. Pati hanjeli dengan modifikasi ozonasi dan kombinasi ultrasonikasi dan ozonasi tidak menghasilkan perubahan pada posisi puncak penyerapan, selain itu tidak ada hilangnya puncak serapan atau munculnya puncak serapan baru, ini mencerminkan tidak ada pembentukan baru atau hilangnya ikatan kimia dan gugus fungsi. Selain itu, pada proses ozonasi maka gas yg digunakan adalah $\mathrm{O}_{3}$ yang akan kembali menjadi oksigen bebas setelah digunakan, sehingga tidak berikatan dengan gugus lain. Hal ini sejalan dengan penelitian lainnya bahwa tidak ada perubahan spektrum FTIR pada pati kentang modifikasi ultrasonikasi (Bai et al., 2017), pati singkong ozonasi (Murdianto et al., 2019b), dan pati barley ozonasi (Halal et al., 2015). 


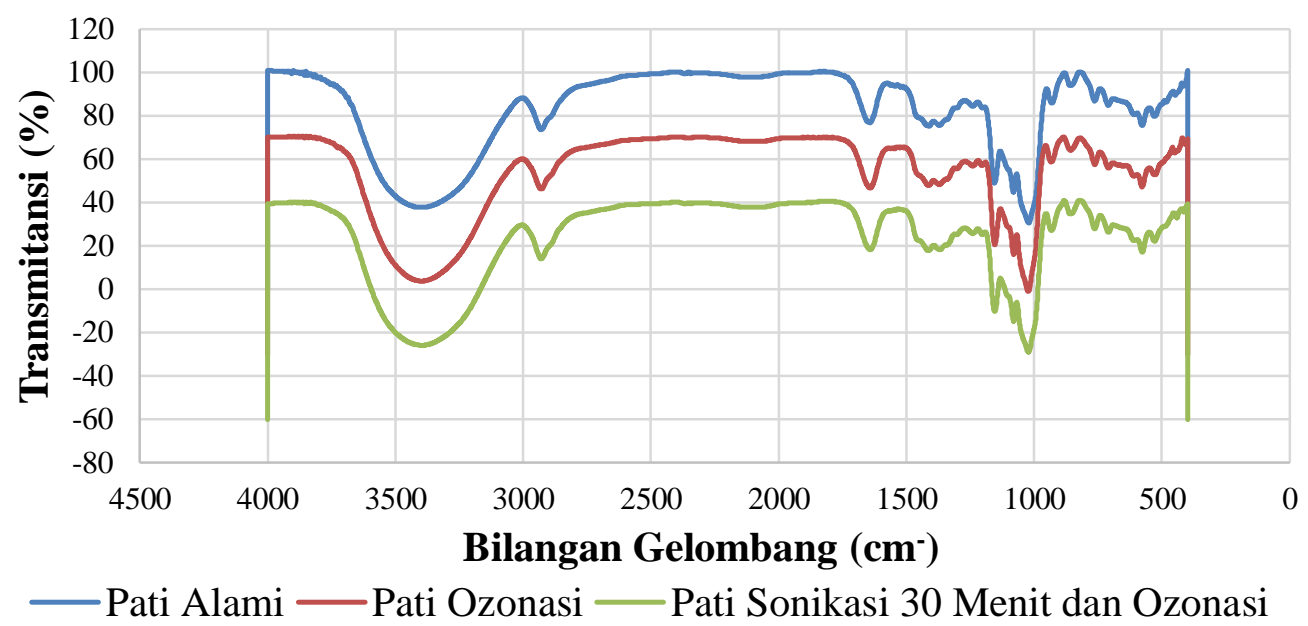

Gambar 2 Spektra Gugus Fungsional Pati Hanjeli dengan FTIR

\section{Sifat Fungsional Pati}

\section{Swelling Volume}

Pembengkakan granula pati tidak hanya dipengaruhi oleh kandungan amilosa, tetapi juga terkait dengan kandungan amilopektin, struktur granula, serta distribusi molekul pati dalam granula pati (Yu et al., 2012). Menurut Ehtiati et al., (2016) pembengkakan pati meningkat dengan cepat, hal ini disebabkan suhu yang semakin meningkat menyebabkan air semakin mudah diserap ke dalam granula pati (Wang et al., 2015). Suhu pemasakan yang digunakan pada pengujian adalah $80^{\circ} \mathrm{C}$, dimana suhu tersebut lebih tinggi daripada suhu gelatinisasi pati hanjeli yang berada pada suhu sekitar $74,4^{\circ} \mathrm{C}$ (Capule dan Trinidad, 2016). Hal ini untuk memastikan bahwa semua granula pati telah membengkak dan tergelatinisasi.

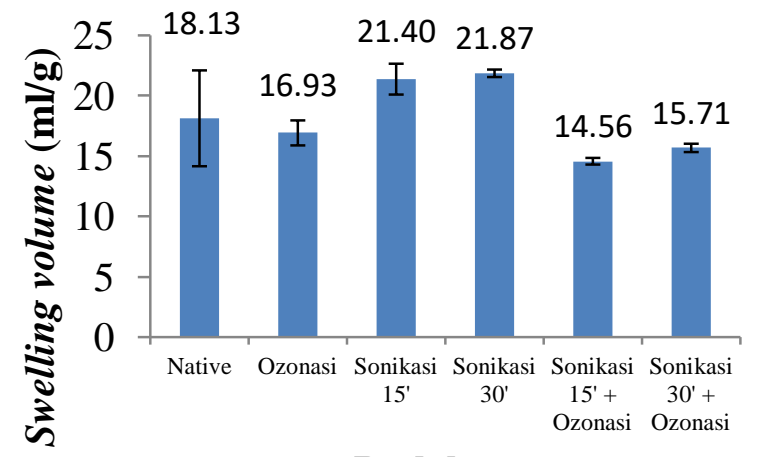

Perlakuan

Gambar 3 Hasil Pengujian Swelling Volume Pati Hanjeli Alami dan Modifikasi
Berdasarkan data hasil penelitian (Gambar 3) dapat dilihat bahwa pati modifikasi ozonasi serta modifikasi kombinasi ultrasonikasi dan ozonasi menghasilkan nilai swelling volume yang lebih rendah daripada pati alami, sedangkan pati modifikasi ultrasonikasi menghasilkan nilai yang lebih tinggi daripada pati alami. Meskipun pati hanjeli hasil ozonasi berdasarkan analisis SEM (Gambar 1) memiliki permukaan granula pati yang berpori tetapi tidak dapat meningkatkan nilai swelling volume, hal ini diduga karena pemecahan molekul amilopektin akibat proses ozonasi menyebabkan pori-pori pada granula meningkatkan penyerapan air selama pemanasan, namun pori-pori lemah dalam menahan air yang diserap saat sentrifugasi, sehingga nilai swelling volume menjadi menurun (Sumardiono et al., 2021).

Pati hanjeli modifikasi ultrasonikasi memiliki swelling volume yang lebih tinggi daripada pati alami. Peningkatkan nilai swelling volume diakibatkan karena modifikasi ultrasonikasi menyebabkan kerusakan fisik granula pati menjadi berpori, sehingga memudahkan penetrasi air dan hidrasi pati (Zhu, 2015). Pati hanjeli modifikasi ultrasonikasi 30 menit memiliki swelling volume yang lebih tinggi dariapada ultrasonikasi 15 menit, hal ini menunjukkan bahwa proses ultrasonikasi selama 30 menit mengakibatkan pati lebih mengalami kerusakan fisik yang ditandai dengan banyak timbulnya pori-pori pada permukaan granula 
pati hanjeli (Gambar 1). Pati modifikasi kombinasi ultrasonikasi dan ozonasi mengalami penurunan swelling volume dibandingkan pati alami. Penurunan swelling volume ini disebabkan karena proses ultrasonikasi membuat permukaan pati hanjeli menjadi berpori sehingga permukaan granula pati menjadi lebih luas, sehingga saat dilakukan proses ozonasi akan lebih banyak permukaan yang terpapar oleh gas ozon. Seperti yang telah dijelaskan sebelumnya, bahwa proses ozonasi akan menghasilkan pori-pori yang meningkatkan penyerapan air selama pemanasan, namun ketika dilakukan sentrifugasi pori-pori lemah dalam menahan air, maka dari itu karena permukaan granula pati dengan kombinasi lebih banyak terpapar gas ozon maka akan menghasilkan pori-pori yang lebih banyak namun lebih lemah juga dalam menahan air setelah dipanaskan sehingga nilai swelling volume menurun. Hasil ini menunjukkan bahwa pori-pori yang terlalu banyak dan lebar juga dapat mendorong terjadinya sineresis atau terlepasnya kembali air yang sudah diserap oleh granula pati.

\section{Kelarutan}

Selama proses gelatinisasi, ketika dipanaskan dengan air granula pati akan menyerap air dan membengkak, dan beberapa komponen pati seperti amilosa akan terlepas dan larut (Moorthy et al., 2018). Kelarutan menunjukkan jumlah molekul pati terlarut pada suhu tertentu (Oladebeye et al., 2013).

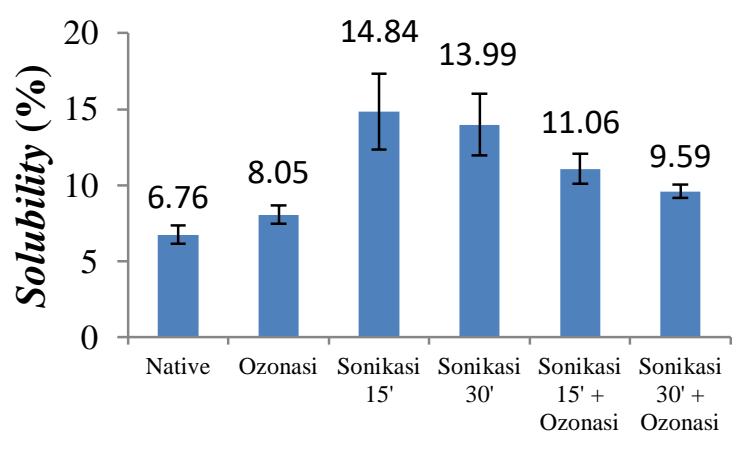

Perlakuan

Gambar 4 Hasil Pengujian Solubility Pati Hanjeli Alami dan Modifikasi

Berdasarkan data hasil penelitian (Gambar 4) dapat dilihat bahwa pati hanjeli ozonasi, ultrasonikasi, dan kombinasi ultrasonikasi dengan ozonasi mengalami peningkatan nilai kelarutan dibandingkan pati alami. Dilihat dari gambar analisis SEM (Gambar 1) pati hanjeli modifikasi memiliki permukaan yang berpori, permukaan pori yang besar atau kecil akan meningkatkan kelarutan pati (Capule and Trinidad, 2016). Peningkatan kelarutan pati teroksidasi dengan ozon disebabkan juga karena melemahnya struktur granula pati sehingga mudah terjadinya leaching amilosa (Murdianto et al., 2019a). Menurut Jambrak et al., (2010), proses ultrasonikasi akan menyerang granula pati khususnya daerah amorf di mana amilosa berada sehingga terjadi kebocoran amilosa di luar granula pati yang mengakibatkan amilosa mudah dilepaskan ke media berair dan kelarutan meningkat. Selain itu, ultrasonikasi menyebabkan perubahan fisik granula pati menjadi berpori, sehingga molekul air lebih mudah berdifusi ke dalam granula, peningkatan asupan air akan meningkatkan leaching amilosa dari daerah amorf (Herceg et al., 2010; Kaur and Gill, 2019). Pati hanjeli modifikasi mengalami kenaikan nilai kelarutan, peningkatan kelarutan ini mengindikasi bahwa pati hanjeli termodifikasi lebih mudah larut dalam air dibandingkan pati hanjeli alami.

\section{Kapasitas Penyerapan Air}

Kapasitas penyerapan air (KPA) merupakan jumlah air yang dapat diserap dan dipertahankan oleh pati, sifat ini sangat penting dalam industri makanan (Nanci Castanha et al., 2019). KPA adalah sifat pati yang berkaitan dengan gugus hidrofilik dalam rantai molekulnya, semakin banyak gugus hidrofilik yang dapat diakses oleh air untuk interaksi melalui ikatan hidrogen, maka semakin tinggi kapasitas pati menyerap air (Wani et al., 2016). 


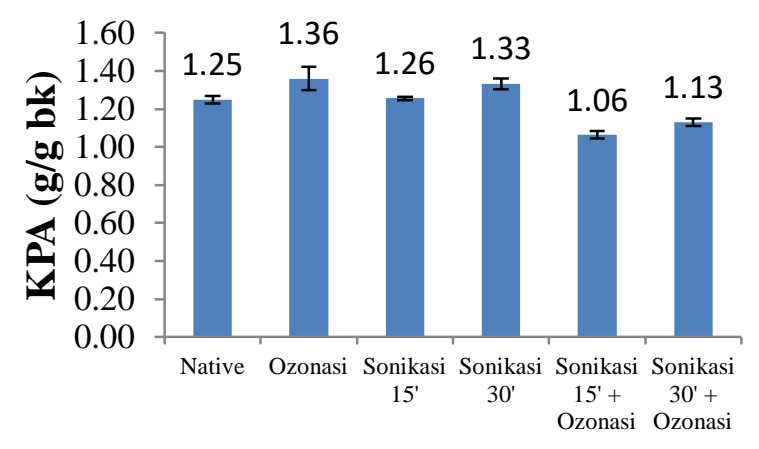

Perlakuan

Gambar 5 Hasil Pengujian Kapasitas Penyerapan Air Pati Hanjeli Alami dan Modifikasi

Berdasarkan data hasil penelitian (Gambar 5) yang telah diuji signifikasi ( $\mathrm{p}<$ $0,05)$ dapat dilihat bahwa pati modifikasi ozonasi serta ultrasonikasi selama 30 menit memiliki nilai KPA yang lebih tinggi dibandingkan pati alami, sedangkan pati modifikasi kombinasi ultrasonikasi selama 15 dan 30 menit dengan ozonasi memiliki nilai yang lebih rendah daripada pati alami. Pati hanjeli ozonasi memiliki nilai kapasitas penyerapan air yang lebih tinggi daripada pati alami. Reaksi ozonasi diduga menyebabkan hidrolisis atau pemecahan sebagian rantai percabangan molekul amilopektin sehingga berubah menjadi molekul rantai lurus, sehingga jumlah amilosa bertambah. Amilosa memiliki sifat hidrofilik, maka dari itu kapasitas penyerapan air meningkat karena banyaknya amilosa yang mengikat air. Selain itu, pati hanjeli ozonasi memiliki permukaan granula berpori yang ukurannya kecil, sehingga menyebabkan air akan lebih banyak terserap dibandingkan dengan pati alami. Pati hanjeli ultrasonikasi selama 15 dan 30 menit mengalami kenaikan nilai kapasitas penyerapan air dari pati alami. Meningkatnya kapasitas penyerapan air disebabkan karena adanya pori-pori pada permukaan granula pati setelah perlakuan ultrasonikasi dilihat dari analisis SEM (Gambar 1). Pori-pori pada permukaan granula pati menyebabkan peningkatan luas permukaannya, sehingga air menjadi lebih banyak terserap (BeMiller and Huber, 2015).
Pati hanjeli ultrasonikasi selama 30 menit memiliki nilai kapasitas penyerapan air yang lebih tinggi daripada ultrasonikasi selama 15 menit. Pati hanjeli modifikasi kombinasi ultrasonikasi dan ozonasi memiliki nilai kapasitas penyerapan air yang lebih rendah dibandingkan pati alami. Menurut Sumardiono et al., (2021) pori-pori yang dihasilkan setelah proses oksidasi bersifat lemah dalam menahan air, hal ini mengakibatkan nilai kapasitas penyerapan air akibat modifikasi kombinasi dan ozonasi lebih rendah dari pati alami. Modifikasi kombinasi ultrasonikasi 30 menit dengan ozonasi memiliki nilai kapasitas penyerapan air yang lebih tinggi dibandingkan ultrasonikasi 15 menit dengan ozonasi, hal ini berkaitan dengan banyaknya pori-pori pada permukaan granula pati dilihat dari analisis SEM (Gambar 1) bahwa modifikasi ultrasonikasi 30 menit dengan ozonasi memiliki pori-pori lebih banyak daripada modifikasi ultrasonikasi 15 menit dengan ozonasi, sehingga akan lebih banyak juga dalam kemampuan menyerap air. Hal ini juga terlihat dari elaborasi karakteristik kapasitas penyerapan air dan swelling volume (Gambar 3 dan Gambar 5) yang juga menunjukkan bahwa modifikasi ultrasonikasi 30 menit dengan ozonasi memiliki kapasitas penyerapan air dan swelling volume yang lebih tinggi daripada modifikasi ultrasonikasi 15 menit dengan ozonasi.

\section{Sifat Amilografi}

Sifat amilografi pati hanjeli dianalisis menggunakan RVA (Rapid Visco Analyzer). Sifat pasta merupakan sifat yang penting ketika pati dipertimbangkan untuk digunakan dalam industri makanan (Zhang et al., 2018). Sifat pasta mencerminkan kualitas pati yang terkait dengan ukuran granula dan struktur kimianya (Katyal et al., 2019; Zeng et al., 2011). Perubahan viskositas selama periode memasak merupakan indikasi stabilitas dan perubahan yang terjadi selama pendinginan, serta menunjukkan konsistensi produk (Kaur et al., 2010). 


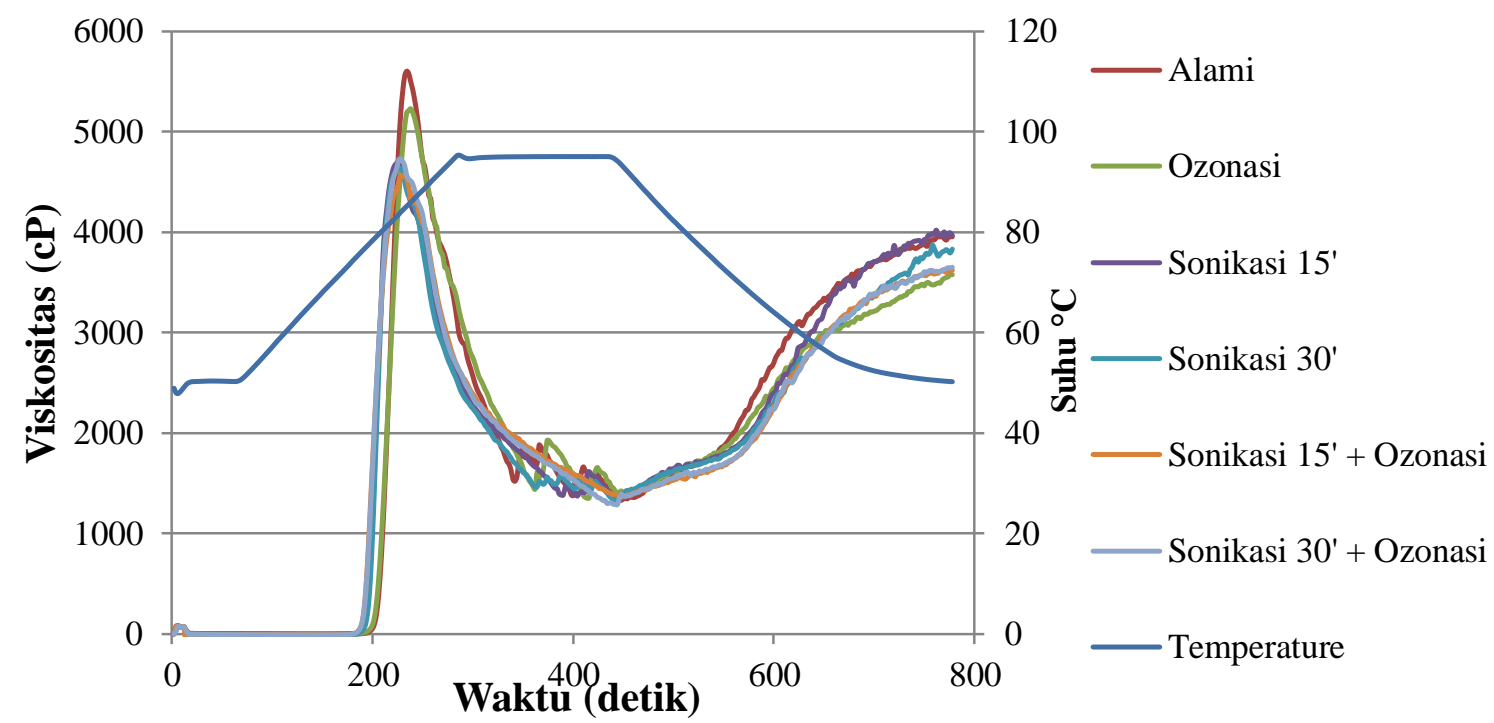

Gambar 6 Kurva amilografi pati hanjeli alami dan modifikasi

Berdasarkan kurva (Gambar 6) dapat diketahui bahwa tipe pasta dari pati hanjeli yaitu tipe A. Tipe A memiliki kemampuan pengembangan tinggi dan menunjukkan viskositas puncak pasta yang tinggi.

Suhu awal gelatinisasi menunjukkan suhu minimum yang diperlukan untuk memasak dan suhu dimana viskositas mulai meningkat selama proses pemanasan (Zhang et al., 2018). Berdasarkan data hasil penelitian Gambar 6 dapat dilihat suhu awal gelatinisasi pati hanjeli tertinggi yaitu pati alami $\left(76,92^{\circ} \mathrm{C}\right)$ dan terendah yaitu pati ultrasonikasi 15 menit dan ozonasi $\left(74,24^{\circ} \mathrm{C}\right)$. Tingginya suhu awal gelatinisasi menunjukkan bahwa pati lebih tahan terhadap pembengkakan dan pecahnya granula pati, sedangkan rendahnya suhu awal gelatinisasi menunjukkan pembengkakan dan pecahnya granula pati paling mudah dalam media air (Du et al., 2014; Li et al., 2011). Viskositas puncak pati hanjeli tertinggi yaitu pati alami (5611 cP) dan terendah yaitu pati ultrasonikasi 15 menit dan ozonasi $(4571 \mathrm{cP})$. Penurunan viskositas puncak akibat ozonasi disebabkan karena adanya degradasi ikatan glikosidik selama proses ozonasi, sehingga pati tidak tahan terhadap geseran dan tidak dapat mempertahankan integritasnya, lalu menghasilkan viskositas yang lebih rendah (Çatal and Ibanoğlu, 2014). Pati hanjeli modifikasi ultrasonikasi selama 15 menit dan 30 menit mengalami penurunan nilai viskositas puncak dari pati alami. Penurunan viskositas disebabkan karena adanya kerusakan fisik granula pati akibat proses ultrasonikasi sehingga meningkatkan penetrasi air untuk hidrasi (Yang et al., 2019).

Pati hanjeli modifikasi kombinasi ultrasonikasi dan ozonasi mengalami penurunan nilai viskositas puncak dibandingkan pati alami. Penurunan viskositas tersebut dapat disebabkan oleh rusaknya granula pati akibat gaya shear sehingga amilosa dipaksa membetuk struktur yang lurus. Struktur lurus amilosa lebih mudah diserang oleh radikal $\mathrm{OH}$ sehingga menurunkan viskositas puncak (Herceg et al., 2010). Viskositas pasta panas pati hanjeli tertinggi yaitu pati ozonasi $(1382 \mathrm{cP})$ dan terendah yaitu pati ultrasonikasi 30 menit dan ozonasi $(1256 \mathrm{cP})$. Nilai viskositas pasta dingin menunjukkan kemampuan pati untuk membentuk pasta atau gel selama pendinginan (Capule and Trinidad, 2016). Viskositas pasta dingin pati hanjeli tertinggi yaitu pati ultrasonikasi 15 menit (3966 cP) dan terendah yaitu pati ozonasi $(3576 \mathrm{cP})$. Nilai viskositas breakdown pada semua pati hanjeli modifikasi mengalami penurunan dari pati alami. Semakin kecil nilai viskositas breakdown maka pati memiliki stabilitas pasta yang semakin baik (Li et al., 2019). viskositas setback pati hanjeli tertinggi yaitu pati ultrasonikasi 15 menit $(2637 \mathrm{cP})$ dan terendah yaitu pati ozonasi (2194 cP). Rendahnya nilai viskositas setback menunjukkan bahwa selama pendinginan pasta pati tidak mudah untuk mengalami 
retrogradasi dan memiliki stabilitas yang lebih tinggi (Li et al., 2019)

\section{KESIMPULAN}

Modifikasi pati hanjeli dengan ozonasi, ultrasonikasi, dan kombinasi keduanya menunjukkan permukaan pati menjadi berpori, dengan modifikasi kombinasi ultrasonikasi 30 menit dan ozonasi menghasilkan pori-pori yang lebih banyak pada permukaan granulanya daripada pati alami. Modifikasi pati hanjeli setelah modifikasi ozonasi dan kombinasi ultrasonikasi dengan ozonasi tidak menghasilkan gugus fungsional yang baru. Sifat fungsional pati hanjeli modifikasi kombinasi ultrasonikasi 30 menit dan ozonasi mengalami penurunan swelling volume dari $18,13 \pm 3,98 \mathrm{ml} / \mathrm{g}$ menjadi $15,71 \pm 0,35 \mathrm{ml} / \mathrm{g}$, peningkatan solubility dari $6,76 \pm 0,62 \%$ menjadi $9,59 \pm 0,44 \%$, dan penurunan kapasitas penyerapan air dari 1,25 $\pm 0,02 \mathrm{~g} / \mathrm{g}$ menjadi $1,13 \pm 0,02 \mathrm{~g} / \mathrm{g}$. Viskositas pasta pati hanjeli dipengaruhi oleh modifikasi ozonasi, ultrasonikasi, dan kombinasi keduanya yaitu secara umum mengalami penurunan pada suhu awal gelatinisasi, viskositas puncak, dan profil gelatinisasi lainnya. Berdasarkan hasil pengujian sifat fisik yang dilakukan, pati hanjeli termodifikasi ini cocok diaplikasikan sebagai absorben dan pada berbagai produk instant.

\section{UCAPAN TERIMA KASIH}

Penulis mengucapkan terima kasih kepada Rektor Universitas Padjadjaran dan Kementerian Pendidikan, Kebudayaan, Riset, dan Teknologi Republik Indonesia atas dukungan yang diberikan.

\section{DAFTAR PUSTAKA}

Amini, A. M., Razavi, S. M. A. dan Mortazavi, S. A. (2015). Morphological, physicochemical, and viscoelastic properties of sonicated corn starch. Carbohydrate Polymers, 122, 282-292. https://doi.org/10.1016/j.carbpol.2015.0 1.020

Ashogbon, A. O. dan Akintayo, E. T. (2014).
Recent trend in the physical and chemical modification of starches from different botanical sources: A review. Starch/Staerke, 66(1-2), 41-57. https://doi.org/10.1002/star.201300106

Bai, W., Hébraud, P., Ashokkumar, M. dan Hemar, Y. (2017). Investigation on the pitting of potato starch granules during high frequency ultrasound treatment. Ultrasonics Sonochemistry, 35, 547555.

https://doi.org/10.1016/j.ultsonch.2016. 05.022

BeMiller, J. N. dan Huber, K. C. (2015). Physical Modification of Food Starch Functionalities. Annual Review of Food Science and Technology, 6(1), 19-69. https://doi.org/10.1146/annurev-food022814-015552

Beuchat, L. R. (1977). Functional and Electrophoretic Characteristics of Succinylated Peanut Flour Protein. Journal of Agricultural and Food Chemistry, 25(2), 258-261. https://doi.org/10.1021/jf60210a044

Cahyana, Y., Titipanillah, R., Mardawati, E., Sukarminah, E., Rialita, T., Andoyo, R., Djali, M., Hanidah, I. I., Setiasih, I. S. dan Handarini, K. (2018). Non-starch contents affect the susceptibility of banana starch and flour to ozonation. Journal of Food Science and Technology, 55(5), 1726-1733. https://doi.org/10.1007/s13197-0183085-2

Capule, A. B. dan Trinidad, T. P. (2016). Isolation and characterization of native and modified starch from adlay (Coix lacryma jobi-L.). International Food Research Journal, 23(3), 1199-1206.

Castanha, N., Lima, D. C., Matta Junior, M. D., Campanella, O. H. dan Augusto, P. E. D. (2019). Combining ozone and ultrasound technologies to modify maize starch. International Journal of Biological Macromolecules, 139, 6374. https://doi.org/10.1016/j.ijbiomac.2019. 07.161 
Castanha, Nanci, Santos, D. N. e., Cunha, R. L. dan Augusto, P. E. D. (2019). Properties and possible applications of ozone-modified potato starch. Food Research International, 116(September 2018), 1192-1201. https://doi.org/10.1016/j.foodres.2018.0 9.064

Çatal, H. dan Ibanoğlu, Ş. (2014). Effect of aqueous ozonation on the pasting, flow and gelatinization properties of wheat starch. LWT - Food Science and Technology, 59(1), 577-582. https://doi.org/10.1016/j.lwt.2014.04.02 5

Chaisiricharoenkul, J., Tongta, S. dan Intarapichet, K. (2011). Structure and Chemical and Physicochemical Properties of Job' S Tear (Coix Lacryma-Jobi L.) Kernels and Flours. Suranaree J.Sci. Technol., 18(2), 109122.

Chemat, F., Zill-E-Huma dan Khan, M. K. (2011). Applications of ultrasound in food technology: Processing, preservation and extraction. Ultrasonics Sonochemistry, 18(4), 813-835. https://doi.org/10.1016/j.ultsonch.2010. 11.023

Collado, L. S. dan Corke, H. (1999). Heatmoisture treatment effects on sweetpotato starches differing in amylose content. Food Chemistry, 65(3), 339-346. https://doi.org/10.1016/S03088146(98)00228-3

Comin, L. M., Temelli, F. dan Saldaña, M. D. A. (2012). Impregnation of flax oil in pregelatinized corn starch using supercritical CO 2. Journal of Supercritical Fluids, 61, 221-228. https://doi.org/10.1016/j.supflu.2011.08. 013

Deka, D. dan Sit, N. (2016). Dual modification of taro starch by microwave and other heat moisture treatments. International Journal of Biological Macromolecules, 92, 416422.

https://doi.org/10.1016/j.ijbiomac.2016.
07.040

Du, S. K., Jiang, H., Ai, Y. dan Jane, J. L. (2014). Physicochemical properties and digestibility of common bean (Phaseolus vulgaris L.) starches. Carbohydrate Polymers, 108(1), 200205.

https://doi.org/10.1016/j.carbpol.2014.0 3.004

Ehtiati, A., Koocheki, A., Shahidi, F., Mohammad, S. dan Razavi, A. (2016). Pasting , rheological and retrogradation properties of starches from dual-purpose sorghum lines. 1-30. https://doi.org/10.1002/star.201600262

Falsafi, S. R., Maghsoudlou, Y., Rostamabadi, H., Rostamabadi, M. M., Hamedi, H. dan Hosseini, S. M. H. (2019). Preparation of physically modified oat starch with different sonication treatments. Food Hydrocolloids, $89, \quad 311-320$. https://doi.org/10.1016/j.foodhyd.2018. 10.046

Halal, S. L. M. El, Colussi, R., Pinto, V. Z., Bartz, J., Radunz, M., Carreño, N. L. V., Dias, A. R. G. dan Zavareze, E. D. R. (2015). Structure, morphology and functionality of acetylated and oxidised barley starches. Food Chemistry, 168, 247-256.

https://doi.org/10.1016/j.foodchem.2014 .07 .046

Herceg, I. L., Jambrak, A. R., Šubarić, D., Brnčić, M., Brnčić, S. R., Badanjak, M., Tripalo, B., Ježek, D., Novotni, D. dan Herceg, Z. (2010). Texture and pasting properties of ultrasonically treated corn starch. Czech Journal of Food Sciences, 28(2), 83-93. https://doi.org/10.17221/50/2009-cjfs

Hu, A., Jiao, S., Zheng, J., Li, L., Fan, Y., Chen, L. dan Zhang, Z. (2015). Ultrasonic frequency effect on corn starch and its cavitation. LWT - Food Science and Technology, 60(2), 941947.

https://doi.org/10.1016/j.lwt.2014.10.04 8 
Hu, A., Li, Y. dan Zheng, J. (2019). Dualfrequency ultrasonic effect on the structure and properties of starch with different size. Lwt, 106(29), 254-262. https://doi.org/10.1016/j.lwt.2019.02.04 0

Jambrak, A. R., Herceg, Z., Šubarić, D., Babić, J., Brnčić, M., Brnčić, S. R., Bosiljkov, T., Čvek, D., Tripalo, B. dan Gelo, J. (2010). Ultrasound effect on physical properties of corn starch. Carbohydrate Polymers, 79(1), 91-100. https://doi.org/10.1016/j.carbpol.2009.0 7.051

Kang, N., Zuo, Y. J., Hilliou, L., Ashokkumar, M. dan Hemar, Y. (2016). Viscosity and hydrodynamic radius relationship of high-power ultrasound depolymerised starch pastes with different amylose content. Food Hydrocolloids, 52, 183-191. https://doi.org/10.1016/j.foodhyd.2015. 06.017

Katyal, M., Singh, N., Chopra, N. dan Kaur, A. (2019). Hard, medium-hard and extraordinarily soft wheat varieties: Comparison and relationship between various starch properties. International Journal of Biological Macromolecules, 123, 1143-1149. https://doi.org/10.1016/j.ijbiomac.2018. 11.192

Kaur, H. dan Gill, B. S. (2019). Effect of high-intensity ultrasound treatment on nutritional, rheological and structural properties of starches obtained from different cereals. International Journal of Biological Macromolecules, 126, 367-375.

https://doi.org/10.1016/j.ijbiomac.2018. 12.149

Kaur, M., Sandhu, K. S. dan Lim, S. T. (2010).

Microstructure, physicochemical properties and in vitro digestibility of starches from different Indian lentil (Lens culinaris) cultivars. Carbohydrate Polymers, 79(2), 349355.

https://doi.org/10.1016/j.carbpol.2009.0 8.017
Li, H., Wang, R., Zhang, Q., Li, G., Shan, Y. dan Ding, S. (2019). Morphological, structural, and physicochemical properties of starch isolated from different lily cultivars grown in China. International Journal of Food Properties, 22(1), 737-757. https://doi.org/10.1080/10942912.2019. 1603998

Li, W., Shu, C., Zhang, P. dan Shen, Q. (2011). Properties of Starch Separated From Ten Mung Bean Varieties and Seeds Processing Characteristics. Food and Bioprocess Technology, 4(5), 814821. https://doi.org/10.1007/s11947010-0421-6

Majzoobi, M., Hedayati, S. dan Farahnaky, A. (2015). Functional properties of microporous wheat starch produced by $\alpha$-amylase and sonication. Food Bioscience, $\quad 11, \quad 79-84$. https://doi.org/10.1016/j.fbio.2015.05.0 01

Mi, X., Wang, W., Gao, J., Long, Y., Xing, F., Wang, X., Xu, F., You, X., Li, S. dan Liu, Y. (2012). Fabrication of highly porous starch monoliths and their application as green desiccants. Polymers for Advanced Technologies, 23(1), $38-47$. https://doi.org/10.1002/pat.1836

Miao, L., Zhao, S., Zhang, B., Tan, M., Niu, M., Jia, C. dan Huang, Q. (2018). Understanding the supramolecular structures and pasting features of adlay seed starches. Food Hydrocolloids, 83, 411-418.

https://doi.org/10.1016/j.foodhyd.2018. 05.034

Moorthy, S. N., Sajeev, M. S. dan Anish, R. J. (2018). Functionality of Tuber Starches. In Starch in Food: Structure, Function and Applications: Second Edition. Elsevier Ltd. https://doi.org/10.1016/B978-0-08100868-3.00011-1

Murdianto, W., Anggrahini, S., . S. dan Pranoto, Y. (2019). Modification of Gajah Cassava Starch Originating from East Borneo, Indonesia, using Ozone 
Oxidation. Pakistan Journal of Nutrition, 18(5), 471-478. https://doi.org/10.3923/pjn.2019.471.47 8

Murdianto, W., Pranoto, Y. dan Anggrahini, S. (2019). Alteration of cassava starch properties after ozone-oxidation treatment in different time. International Journal of Food Science and Nutrition International, 4(5), 5660 .

Oladebeye, A. O., Oshodi, A. A., Amoo, I. A. dan Karim, A. A. (2013). Functional, thermal and molecular behaviours of ozone-oxidised cocoyam and yam starches. Food Chemistry, 141(2), 1416-1423.

https://doi.org/10.1016/j.foodchem.2013 .04 .080

Przetaczek-Rożnowska, I., Fortuna, T., Wodniak, M., Łabanowska, M., Pająk, P. dan Królikowska, K. (2019). Properties of potato starch treated with microwave radiation and enriched with mineral additives. International Journal of Biological Macromolecules, 124, 229-234.

https://doi.org/10.1016/j.ijbiomac.2018. 11.153

Sandhu, H. P. S., Manthey, F. A. dan Simsek, S. (2012). Ozone gas affects physical and chemical properties of wheat (Triticum aestivum L.) starch. Carbohydrate Polymers, 87(2), 12611268.

https://doi.org/10.1016/j.carbpol.2011.0 9.003

Subroto, E., Indiarto, R., Marta, H. dan Shalihah, S. (2019). Effect of heat moisture treatment on functional and pasting properties of potato (Solanum tuberosum L. var. Granola) starch. Food Research, 3(5), 469-476. https://doi.org/10.26656/fr.2017.3(5).11 0

Sujka, M. dan Jamroz, J. (2013). Ultrasoundtreated starch: SEM and TEM imaging, and functional behaviour. Food Hydrocolloids, 31(2), 413-419. https://doi.org/10.1016/j.foodhyd.2012.
11.027

Sumardiono, S., Cahyono, H., Jos, B., Pudjihastuti, I., Yafiz, A. M. dan Rachmasari, M. (2021). Physicochemical properties of sago ozone oxidation: The effect of reaction time, acidity, and concentration of starch. Foods, 10(6). https://doi.org/10.3390/foods10061309

Wang, S., Wang, J., Zhang, W., Li, C., Yu, J. dan Wang, S. (2015). Molecular order and functional properties of starches from three waxy wheat varieties grown in China. Food Chemistry, 181, 43-50. https://doi.org/10.1016/j.foodchem.2015 .02 .065

Wani, I. A., Sogi, D. S., Hamdani, A. M., Gani, A., Bhat, N. A. dan Shah, A. (2016). Isolation, composition, and physicochemical properties of starch from legumes: A review. Starch/Staerke, 68(9-10), 834-845. https://doi.org/10.1002/star.201600007

Wu, Y., Du, X., Ge, H. dan Lv, Z. (2011). Preparation of microporous starch by glucoamylase and ultrasound. Starch/Staerke, 63(4), 217-225. https://doi.org/10.1002/star.201000036

Yang, W., Kong, X., Zheng, Y., Sun, W., Chen, S., Liu, D., Zhang, H., Fang, H., Tian, J. dan Ye, X. (2019). Controlled ultrasound treatments modify the morphology and physical properties of rice starch rather than the fine structure. Ultrasonics Sonochemistry, 59, 104709. https://doi.org/10.1016/j.ultsonch.2019. 104709

Yu, S., Ma, Y., Menager, L. dan Sun, D. W. (2012). Physicochemical Properties of Starch and Flour from Different Rice Cultivars. Food and Bioprocess Technology, 5(2), 626-637. https://doi.org/10.1007/s11947-0100330-8

Zeng, J., Li, G., Gao, H. dan Ru, Z. (2011). Comparison of A and $\mathrm{B}$ starch granules from three wheat varieties. Molecules, 16(12), 10570-10591. https://doi.org/10.3390/molecules 16121 
0570

Zhang, B., Cui, D., Liu, M., Gong, H., Huang, Y. dan Han, F. (2012). Corn porous starch: Preparation, characterization and adsorption property. International Journal of Biological Macromolecules, 50(1), 250256.

https://doi.org/10.1016/j.ijbiomac.2011. 11.002

Zhang, Y., Hu, M., Zhu, K., Wu, G. dan Tan, L. (2018). Functional properties and utilization of Artocarpus heterophyllus Lam seed starch from new species in China. In International Journal of Biological Macromolecules (Vol. 107). Elsevier B.V. https://doi.org/10.1016/j.ijbiomac.2017. 10.001

Zhu, F. (2015). Impact of ultrasound on structure, physicochemical properties, modifications, and applications of starch. Trends in Food Science and Technology, 43(1), 1-17. https://doi.org/10.1016/j.tifs.2014.12.00 8

Zhu, F. (2017). Coix: Chemical composition and health effects. Trends in Food Science and Technology, 61, 160-175. https://doi.org/10.1016/j.tifs.2016.12.00 3

Zuo, J. Y., Knoerzer, K., Mawson, R., Kentish, S. dan Ashokkumar, M. (2009). The pasting properties of sonicated waxy rice starch suspensions. Ultrasonics Sonochemistry, 16(4), 462468.

https://doi.org/10.1016/j.ultsonch.2009. 01.002 